\title{
Assessment of knowledge on pharmacotherapeutics among undergraduate medical students in a South Indian medical college
}

\author{
Surekha Palacherla, Bheemesh Naidu Mattam*, Kodanda Ramu Burli, Sachidananda Moorthy
}

Department of Pharmacology, Maharajah's Institute of Medicine Sciences, Vizianagaram, Andhra Pradesh, India

\author{
Received: 20 January 2020 \\ Revised: 29 May 2020 \\ Accepted: 06 June 2020 \\ *Correspondence: \\ Dr. Bheemesh Naidu Mattam, \\ Email: bheemesh6@gmail.com
}

Copyright: (c) the author(s), publisher and licensee Medip Academy. This is an open-access article distributed under the terms of the Creative Commons Attribution Non-Commercial License, which permits unrestricted non-commercial use, distribution, and reproduction in any medium, provided the original work is properly cited.

\begin{abstract}
Background: Pharmacotherapeutics knowledge is important for rational drug therapy. Assessment of knowledge on emergency and non-emergency medical conditions in medical students will be helpful to develop a methodological approach in building knowledge on patient care and in improving quality of medical education.

Methods: It was a questionnaire based cross- sectional study conducted among undergraduate medical students in MIMS college after taking Institutional ethical committee permission. The students of final MBBS part-I and final MBBS part-II and house surgeons were given semi-structured questionnaires. It constitutes questions on awareness of pharmacotherapeutics of non-emergency (20) and emergency (8) medical conditions.

Results: Received a total of 284 responses, of them $43.32 \%, 39.43 \%$ and $17.25 \%$ are from final MBBS part-I, final MBBS part-II and house surgeons respectively. 48.1\% students agreed that undergraduate training sufficient to confidently give a safe prescription to the patient. The overall knowledge of the students in pharmacotherapeutics relating to certain non-emergency conditions is found to be $64.89 \%$ and relating to emergency conditions, it is $62.98 \%$.

Conclusions: Knowledge on emergency and non-emergency PT is moderate. Appropriate training programs are needed to improve this situation. Regular evaluative measures also help to overcome the present situation.
\end{abstract}

Keywords: Rational drug use, Pharmacotherapeutics, Non-emergency, Emergency medical conditions

\section{INTRODUCTION}

Knowledge of pharmacotherapeutics plays an important role in treating ailments effectively. Pharmacotherapeutics (PT) is the application of pharmacological information together with the knowledge of the disease for its prevention, mitigation or cure. ${ }^{1}$ Selection of the most appropriate drug, dosage and duration of treatment taking into account the specific features of a patient are a part of PT. ${ }^{2}$

The conference of experts on the rational use of medicines, convened by the World Health Organization
(WHO) in Nairobi 1985, stated that rational use of medicines requires that patients receive medications appropriate to their clinical needs, in doses that meet their own individual requirements for an adequate period of time, at the lowest cost. ${ }^{3}$ Therefore, PT knowledge is a prerequisite for rational prescribing and prepares the medical undergraduates to be efficient doctors.

Very few studies have been conducted to find the PT knowledge of medical students. These studies reported deficiency in PT knowledge. ${ }^{4,5}$ The present study aims at assessing knowledge of undergraduate medical students on pharmacotherapeutics. 


\section{METHODS}

This was a cross-sectional study conducted among undergraduate medical students of final MBBS part-I and final MBBS part-II and house surgeons. Institutional ethical committee (IEC) clearance had been taken prior to starting of the study. Strict anonymity was maintained about the test results. Study was conducted in MIMS, Nellimarla, A.P, in the month of March-April 2019.

Questionnaires were distributed to the students after taking informed consent. The questionnaire constitutes general information of the students, questions on awareness on pharmacotherapeutics, 20 questions relating to non-emergency medical conditions and 8 questions relating to emergency medical conditions of pharmacotherapeutics. The obtained data was statistically analyzed using microsoft excel.

\section{RESULTS}

The questionnaire was distributed to a total of 300 students belonging to final MBBS part-I, final MBBS part-II and house surgeons, and a total of 284 students had filled the given forms. Out of 284 students, the responses from males and females are $27.6 \%$ and $72.4 \%$ respectively.

Table 1: Demographic information.

\begin{tabular}{|ll|}
\hline Characteristics & Responses in percentage \\
\hline Sex & \\
\hline Male & 27.6 \\
\hline Female & 72.4 \\
\hline Year of study & \\
\hline Final MBBS part I & 43.32 \\
\hline Final MBBS part II & 39.43 \\
\hline House surgeons & 17.25 \\
\hline
\end{tabular}

Table 2: Awareness on pharmacotherapeutics.

\begin{tabular}{|c|c|}
\hline Characteristics & Responses in percentage \\
\hline $\begin{array}{l}\text { Definition of } \\
\text { pharmacotherapeutics }\end{array}$ & 59.7 \\
\hline \multicolumn{2}{|c|}{$\begin{array}{l}\text { Trained regarding pharmacotherapeutics during } \\
\text { pharmacology in 2nd year under graduation }\end{array}$} \\
\hline Yes & 80.6 \\
\hline No & 19.4 \\
\hline \multicolumn{2}{|c|}{$\begin{array}{l}\text { Undergraduate training sufficient to } \\
\text { give a safe prescription }\end{array}$} \\
\hline Agree & 48.1 \\
\hline Disagree & 51.9 \\
\hline \multicolumn{2}{|c|}{$\begin{array}{l}\text { Most important factor considered while prescribing } \\
\text { a drug }\end{array}$} \\
\hline Safety and cost & 10.6 \\
\hline Safety and efficacy & 72.7 \\
\hline Efficacy and cost & 16.7 \\
\hline
\end{tabular}

Table 3: Non-emergency conditions.

\begin{tabular}{|c|c|}
\hline Questions & $\begin{array}{l}\text { Percentage of } \\
\text { positive response }\end{array}$ \\
\hline $\begin{array}{l}\text { Drug of choice in a case of } \\
\text { uncomplicated early type } 2 \\
\text { diabetes mellitus? }\end{array}$ & 91 \\
\hline $\begin{array}{l}\text { As per JNC } 8 \text { classification of } \\
\text { hypertension, first line anti- } \\
\text { hypertensive drugs used are all, } \\
\text { except? }\end{array}$ & 33.3 \\
\hline $\begin{array}{l}\text { Drugs used commonly in } \\
\text { allergic conditions are all } \\
\text { except? }\end{array}$ & 15.8 \\
\hline $\begin{array}{l}\text { Drug of choice for non - } \\
\text { complicated non- resistant } \\
\text { malaria? }\end{array}$ & 72.7 \\
\hline $\begin{array}{l}\text { RNTCP regimen of a newly } \\
\text { diagnosed case of smear positive } \\
\text { pulmonary tuberculosis? }\end{array}$ & 87.8 \\
\hline $\begin{array}{l}\text { Drugs used in treatment of } \\
\text { leprosy are all except? }\end{array}$ & 83.1 \\
\hline $\begin{array}{l}\text { Drugs for the treatment of } \\
\text { migraine are all, except? }\end{array}$ & 63 \\
\hline $\begin{array}{l}\text { Most effective drug in the } \\
\text { treatment of peptic ulcer? }\end{array}$ & 76.6 \\
\hline $\begin{array}{l}\text { Following are some of the drugs } \\
\text { used in motion sickness, except? }\end{array}$ & 39.5 \\
\hline $\begin{array}{l}\text { Which of the following is not a } \\
\text { fixed dose combination? }\end{array}$ & 44.2 \\
\hline $\begin{array}{l}\text { Dosage of iron in pregnant } \\
\text { women? }\end{array}$ & 61.3 \\
\hline $\begin{array}{l}\text { Most common adverse drug } \\
\text { effect of non-selective cyclo- } \\
\text { oxygenase inhibitors? }\end{array}$ & 83.6 \\
\hline $\begin{array}{l}\text { Contraindications of cortico- } \\
\text { steroidal therapy are all, } \\
\text { except? }\end{array}$ & 47.4 \\
\hline $\begin{array}{l}\text { Therapeutic dose of } \\
\text { paracetamol in children? }\end{array}$ & 56 \\
\hline $\begin{array}{l}\text { Drug of choice to treat adult } \\
\text { hypothyroidism? }\end{array}$ & 66.7 \\
\hline $\begin{array}{l}\text { Most widely used local } \\
\text { anaesthetic drug? }\end{array}$ & 92.2 \\
\hline $\begin{array}{l}\text { Drugs contraindicated during } \\
\text { pregnancy are all, except? }\end{array}$ & 85.5 \\
\hline $\begin{array}{l}\text { Following are the anti-glaucoma } \\
\text { drugs, except? }\end{array}$ & 73.3 \\
\hline First line drug for enteric fever? & 56.4 \\
\hline $\begin{array}{l}\text { Drug of choice for } \\
\text { Pseudomembranous colitis? }\end{array}$ & 68.4 \\
\hline
\end{tabular}

$51.9 \%$ of the students exhibit lack of confidence, while the remaining $48.1 \%$ of the students are confident that their undergraduate training is sufficient to give a safe prescription to the patients. $72.7 \%$ of students opined that safety and efficacy is the most important factor considered while prescribing a drug. 
The overall knowledge of the students in pharmacotherapeutics relating to certain non-emergency conditions is found to be $64.89 \%$. Most of the students, $92.2 \%$ and $91 \%$ could correctly answer the most widely used anaesthetics drug and the drug of choice in treating early uncomplicated type II diabetes mellitus respectively.

The overall knowledge of the students in pharmacotherapeutics relating to emergency conditions is $62.98 \%$. Majority of the students $93.5 \%$ correctly identified the drug of choice used to relieve acute angina.

Table 4: Emergency conditions.

\begin{tabular}{|l|l|}
\hline Questions & $\begin{array}{l}\text { Percentage of } \\
\text { correct response }\end{array}$ \\
\hline $\begin{array}{l}\text { Life-saving drug in } \\
\text { anaphylactic shock? }\end{array}$ & 88.3 \\
\hline $\begin{array}{l}\text { First line drug for status } \\
\text { epilepticus? }\end{array}$ & 63.2 \\
\hline $\begin{array}{l}\text { I.V. fluid of choice to correct } \\
\text { severe dehydration? }\end{array}$ & 61 \\
\hline $\begin{array}{l}\text { First line drug useful in the } \\
\text { management of status } \\
\text { asthmaticus? }\end{array}$ & 79 \\
\hline $\begin{array}{l}\text { Insulin preparation used to } \\
\text { treat diabetic ketoacidosis? }\end{array}$ & 31 \\
\hline $\begin{array}{l}\text { Drug of choice in relieving acute } \\
\text { angina? }\end{array}$ & 93.5 \\
\hline $\begin{array}{l}\text { Drugs useful in hypertensive } \\
\text { emergency are all, except? }\end{array}$ & 35.2 \\
\hline $\begin{array}{l}\text { Dose of atropine to reverse } \\
\text { muscarinic effects in } \\
\text { organophosphorus poisoning? }\end{array}$ & 52.6 \\
\hline
\end{tabular}

\section{DISCUSSION}

$48.1 \%$ of the students are confident that their undergraduate training is sufficient to give a safe prescription to the patients. In a study from India by Sharma et al, 7.5-81.6\% medical students considered themselves competent to prescribe anti-microbials for various infections. ${ }^{6}$

Most important factor while prescribing a drug is considered to be safety and efficacy by $72.7 \%$ of the students, and safety and cost and efficacy and cost by $10.6 \%$ and $16.7 \%$ of the students respectively. This is similar to the results obtained by Khan et al study 2016 and they think that there is a scope of improvement in their knowledge and perception towards PT. ${ }^{7}$

Metformin is an old but still the best treatment for type 2 diabetes mellitus. ${ }^{8} 91 \%$ of the students correctly answered the drug of choice to treat uncomplicated early type 2 diabetes mellitus as metformin.
Beta blockers are no longer first choice drugs as per the joint national committee 8 recommendation about treatment of hypertension, which is known to only $33.3 \%$ of the students. ${ }^{9}$

In the United States, the recommended primary therapy for Pylori infection is proton pump inhibitor (PPI) based triple therapy, and the drug of choice for peptic ulcer is correctly answered by $76.6 \%$ of the students. ${ }^{10}$

The drugs commonly used in allergic conditions are known to $15.8 \%$ of the students. The primary drug treatments for acute anaphylactic reactions are epinephrine and $\mathrm{H} 1$ antihistamines. Corticosteroids are potentially effective in preventing biphasic (i.e., recurrent) reactions. ${ }^{11}$

Non-selective cyclooxygenase inhibitors are one of the most commonly prescribed drugs for various painful inflammatory conditions and are also the leading cause of adverse drug reactions. ${ }^{12}$ Gastric mucosal damage and peptic ulcer is the most common adverse effect of NSAIDs is known to $83.6 \%$ of the students. Paracetamol is the most common anti-pyretic drug used in pediatric population, its dose calculation is expected to be known to students, $56 \%$ of the students could correctly answer the same. $63 \%$ could correctly identify that tramadol, an opioid analgesic is not effective in the treatment of migraine. $^{13}$

Tetracyclines, NSAIDs, ACEi's are some of the drugs contraindicated in pregnancy. Folic acid, a nutritional supplement can safely be used during pregnancy and is no contraindication is known to $85.5 \%$ of the students. ${ }^{14}$

Pseudomembranous colitis is a known adverse effect of antibiotics like cephalosporins, tetracyclines, and clindamycin, but can be treated effectively by metronidazole was correctly answered by $68.4 \%$ of the students.

Fluroquinolone (ciprofloxacin and ofloxacin) have for some years been the drugs of choice for enteric fever, but resistance to these drugs has become very common in South Asia. Therefore, currently ceftriaxone could be the drug of choice in the treatment of enteric fever. ${ }^{15}$ It is known to only $56.4 \%$ of the students.

The 2015 WHO guidelines for the treatment of malaria state that, if the species cannot be confirmed, the patient should be managed as if the infection is caused by $P$. falciparum and in areas of chloroquine sensitivity, chloroquine should be used. ${ }^{16}$ The drug of choice in a case of non-resistant and non-complicated malaria is known to $72.7 \%$ of students.

Tuberculosis (TB) is a serious health care problem in India. A national program is being run for tackling it in the form of revised national TB control program (RNTCP). ${ }^{17}$ Therefore, it is expected by the students to 
know the treatment regimens to treat the condition. RNTCP regimen to treat a newly diagnosed case of smear positive pulmonary tuberculosis is known to $87.8 \%$ of the students.

Iron deficiency anemia is extremely common, particularly in the developing world. Iron deficiency during pregnancy is one of the leading causes of anemia in infants and young children. ${ }^{18}$ Therefore the students were expected to know the dosage of iron therapy in pregnancy and it is known only to $61.3 \%$ of the students.

Labyrinthine suppressants such as anticholinergics and anti-histaminic with anticholinergic property have been found to be useful in the prevention of motion sickness. Metoclopramide is an anti-emetic which prominently works by blocking D2 receptor in vomiting center and is not a labyrinthine suppressant, therefore not effective in prevention of motion sickness. ${ }^{19}$ However, it was correctly identified by only $39.5 \%$ of the students, showing lack of knowledge about this condition.

Amoxicillin is active against penicillin $\mathrm{G}$ sensitive grampositive and some gram-negative organisms. Cloxacillin is a penicillinase resistant penicillin having lesser activity against penicillin $\mathrm{G}$ sensitive organisms. Their combination does not enhance spectrum and potency, therefore is irrational. ${ }^{20}$ Only $44.2 \%$ of the students could correctly identify thesame, showing a deficient knowledge regarding this group of drugs and their fixed dose combinations.

Drug of choice in relieving acute angina is correctly identified by $93.5 \%$ of the students. Sublingual nitroglycerin has been the mainstay of treatment for angina pectoris. Sublingual nitroglycerin can be used for acute relief of angina and prophylactically before activities that may precipitate angina. ${ }^{21}$

Life-saving drug in anaphylactic shock is correctly identified by $88.3 \%$ of the students. Anaphylaxis is a lifethreatening reaction where prompt and appropriate management can save lives. Epinephrine (adrenaline) is the treatment of choice. ${ }^{22}$

First line drug in the management of status asthmaticus is known to $79 \%$ of the students. Treatment for acute, severe asthma includes the administration of oxygen, $\beta 2$ agonists (by continuous or repetitive nebulization), and systemic corticosteroids. $^{23}$

Organophosphorus pesticide self-poisoning is an important clinical problem in rural regions of the developing world and is a common medical emergency condition which is treated with atropine. ${ }^{24}$ The dose of the drug is known only to $52.6 \%$ of the students.

The overall knowledge of the students in pharmacotherapeutics relating to certain non-emergency conditions is found to be $64.89 \%$ and relating emergency conditions, it is $62.98 \%$. A European study reported knowledge of clinical pharmacology and pharmacotherapy in the range of $65.3-79.2 \%$ among medical students using different set of parameters i.e., pharmacokinetics, pharmacodynamics, prescribing in special group, drug interactions etc. ${ }^{25} \mathrm{~A}$ Chinese multicentric study reported lack of knowledge about rational antibiotic use among 27.4-92.9\% medical students. $^{26}$

The students of the present study were found to have moderate degree of knowledge. There is a need to improve knowledge relating to management of emergency hypertension and to be updated with the latest guidelines of JNC classification, management of allergic conditions and also regarding antibiotics prescription and also management of certain emergency conditions.

This is a single center study involving limited numbers of participants. A large multicentric study may provide greater insight into the level of PT knowledge acquired by medical undergraduates in India. Questions are related with limited drugs and clinical settings; however, it gives an idea about the status of knowledge of PT among undergraduate medical students.

\section{CONCLUSION}

The general awareness on pharmacotherapeutics was found to be good among the students. The knowledge on certain non-emergency and emergency medical conditions is found to be of moderate degree and is high when compared to a similar study conducted in India. However, there is a scope for further improvement in their knowledge. Regular emphasis on pharmacotherapy is to be continued in each year of their study. Appropriate training programs are needed to improve this situation. Regular evaluative measures also help to overcome the present situation.

Funding: No funding sources Conflict of interest: None declared

Ethical approval: The study was approved by the Institutional Ethics Committee

\section{REFERENCES}

1. Tripathi KD. Essentials of Medical Pharmacology. 7th ed. Introduction, routes of drug administration, New Delhi: Jaypee Brothers Medical Publisher. 2014: 765-786.

2. Khan SA, Siddiqui NI. Pharmacotherapeutics knowledge of some non-emergency and emergency conditions among medical undergraduates in an Indian medical college. Indian $\mathbf{J}$ Pharmacol. 2016;48(3):252-7.

3. Brahma D, Marak M, Wahlang J. Rational Use of Drugs and Irrational Drug Combinations. Internet $\mathbf{J}$ Pharmacol. 2012;10(1):1-9. 
4. Dyar OJ, Pulcini C, Howard P, Nathwani D. ESGAP (ESCMID Study Group for Antibiotic Policies). European medical students: a first multi-centre study of knowledge, attitudes and perceptions of antibiotic prescribing and antibiotic resistance. J Anti-microb Chemother. 2014;69:8426.

5. Keijsers CJ, Brouwers JR, Wildt DJ, Custers EJ, Cate OT, Hazen AC, et al. Acomparison of medical and pharmacy students' knowledge and skills of pharmacology and pharmacotherapy. Br J Clin Pharmacol. 2014;78:781-8.

6. Sharma K, Jain P, Sharma A. Knowledge, attitude and perception of medical and dental undergraduates about anti-microbial stewardship. Indian $\mathbf{J}$ Pharmacol. 2015;47:676-9.

7. Khan SA, Siddiqui NI. Pharmacotherapeutics knowledge of some non-emergency and emergency conditions among medical undergraduates in an Indian medical college. Indian J Pharmacol. 2016; 48(3):252-7.

8. Rojas LBA, Gomes MB. Metformin: an old but still the best treatment for type 2 diabetes. Diabetology Metabolic Syndrome. 2013;5:6.

9. James PA, Oparil S, Carter BL, Cushman WC, Himmelfarb DC, Handler J. Evidence based guideline for the management of high blood pressure in adults: Report from the panel members appointed to the eighth joint national committee (JNC8). JAMA. 2013;311(5):507-20.

10. Chey WD, Wong BC. American College of Gastroenterology guideline on the management of Helicobacter pylori infection. Am J Gastroenterol. 2007;102(8):1808-25.

11. Mustafa SS. Anaphylaxis Medication. Available at http://emedicine.medscape.com/article/135065medication\#1. Accessed on 16 May 2018.

12. Pirmohamed M, James S, Makin S, Green C, Scott AK, Walley TJ, et al. Adverse drug reactions as cause of admission to hospital: prospective analysis of 18820 patients. BMJ. 2004;329:15-9.

13. Tepper SJ. Opioids should not be used in migraine. Headache. 2012;52:30-4.

14. Sachdeva P, Patel BG, Patel BK. Pregnancy and Drug Use. Indian J Pharm Sci. 2009;71(1):1-7.

15. Basnyat B. The treatment of enteric fever. J R Soc Med. 2007;100(4):161-2.

16. World Health Organization (WHO). Guidelines for the Treatment of Malaria. 3rd Edition. World Health Organization, Geneva, Switzerland: WHO Press;
2015. Available at https://www.who.int/malaria/ publications/atoz/9789241549127/en. Accessed on 18 January 2018.

17. Verma R, Khanna P, Mehta B. Revised national tuberculosis control program in India: the need to strengthen. Int J Prev Med. 2013;4(1):1-5.

18. Noran M, Ouf A, Mohammed MJ. The impact of maternal iron deficiency and iron deficiency anemia on child's health. Saudi Med J. 2015;36(2):146-9.

19. Sharkey KA, Wallace JL. Treatment of disorders of bowel motility and water flux; anti-emetics; agents used in biliary and pancreatic disease. In: Brunton LL, Chabner BA, Knollmann BC, editors. Goodman and Gilman's, the pharmacological basis of therapeutics. 12th edition. New Delhi: McGraw Hill; 2011: 1323-1349.

20. Petri WA. Penicillins, cephalosporins and other $\mu$ Lactam antibiotics. In: Brunton LL, Chabner BA, Kohlmann BC, editors. Goodman and Gilman's, the pharmacological basis of therapeutics. 12th ed. New Delhi: McGraw Hill; 2011: 1477-1503.

21. Lacoste LL, Theroux P, Lidon RM. Antithrombotic properties of transdermal nitroglycerin instable angina pectoris. Am J Cardiol. 1994;73(15):1058-62.

22. Jose R, Clesham GJ. Survey of the use of epinephrine (adrenaline) for anaphylaxis by junior hospital doctors. Postgrad Med J. 2007;83(983):610-1.

23. Papiris S, Kotanidou A, Malagari K, Roussos C. Clinical review: severe asthma. Crit Care. 2002;6(1):30-44.

24. Eddleston M, Nick A, Eyer BP, Dawson AH. Management of acute organophosphorus pesticide poisoning. Lancet. 2008;371(9612):597-607.

25. Johannsen W, Frings B, Herzig S. Development of perceived pharmacological deficits of medical students and alumni supports claim for continuous and more application-oriented education. Naunyn Schmiedeberg's Arch Pharmacol. 2019;392:29-36.

26. Huang Y, Gu J, Zhang M, Ren Z, Yang W, Chen Y, et al. Knowledge, attitudes and practice of antibiotics: A questionnaire study among 2500 Chinese students. BMC Med Edu. 2013;13:163.

Cite this article as: Palacherla S, Mattam BN, Burli KR, Moorthy S. Assessment of knowledge on pharmacotherapeutics among undergraduate medical students in a South Indian medical college. Int J Basic Clin Pharmacol 2020;9:1119-23. 